\title{
SEGMENTED MECHANICS FOR TRACTION OF IMPACTED MAXILLARY CANINE: CASE REPORT WITH A 3-YEAR FOLLOW-UP
}

\author{
MECÂNICA SEGMENTADA PARA TRACIONAMENTO DE CANINO SUPERIOR \\ IMPACTADO: RELATO DE CASO COM ACOMPANHAMENTO DE 3 ANOS
}

\section{Anderson Paulo Barbosa LIMA'; Pedro Augusto COSTA ${ }^{2}$; Natália Maria Vieira BARBOSA ${ }^{3}$; Renata Rodrigues ALEMIDA-PEDRIN ${ }^{4}$; Luiz Renato PARANHOS ${ }^{5}$; Mauricio de Almeida CARDOSO ${ }^{6}$}

1. Private practice, São Lourenço, Minas Gerais, Brazil; 2.Private practice, Ponta Porã, Mato Grosso do Sul, Brazil; 3. Private practice, Rio de Janeiro, Rio de Janeiro, Brazil; 4. Health Sciences Center, Universidade do Sagrado Coração, Bauru, SP, Brazil; 5. Department of Preventive and Social Dentistry, School of Dentistry, Federal University of Uberlândia, Uberlândia, Minas Gerais, Brazil; 6.Faculdade São Leopoldo Mandic, Campinas, Brazil. dr.andersondentista@ hotmail.com

\begin{abstract}
Young patients are increasingly concerned with smile aesthetics, resulting in the early visit to the dental office. It is of great importance that professionals such as orthodontists, pediatric dentists, and general practitioners are aware of the potential changes in positioning and development that may compromise aesthetics, considering they may prevent future complex orthodontic treatments. This case report describes the treatment of a patient aged 9 years and 4 months, who complained at assessment about the size and position of maxillary incisors. Clinically, the patient presented atresic maxilla and eruption of teeth 12 and 22. The poor positioning of tooth 22 alerted for the potential retention of tooth 23. A two-phase treatment was proposed, including an intercepting phase and a corrective phase. In the intercepting phase, rapid maxillary expansion (RME) was performed, which increased the room for eruption of tooth 23 and prevented the collapse of tooth 22. After the activation period, the Haas expander was locked and removed six months later. Twenty-five months after the removal, the second phase started with fixed corrective orthodontics and traction of tooth 23, for which the enamel was drilled and traction was performed using the segmented technique with a 0.019" $\mathrm{x}$ 0.025" Titanium Molybdenum Alloy (TMA) cantilever and anchorage in passive transpalatal arch (PTA). The use of this technique minimizes the side effects on the teeth adjacent to tooth 23 and enamel drilling prevents potential losses of the traction device by detachment. After 4 months of segmented mechanics, the devices were removed and the PTA was maintained. Twenty-six months later, the patient was 14 years and 4 months old, presenting direct subdivision Class III molar relationship, upper and lower crowding, and unsatisfactory relationship between bone bases due to the excessive mandibular growth. A new RME was performed, and after 3 months a Capelozza Pattern III fixed appliance was installed in the lower arch. Additionally, an upper fixed appliance was installed after the RME retention period. One year and 4 months later, the appliances were removed and a maxillary Hawley plate was installed with a 0.6- $\mathrm{mm}$ fixed mandibular intercanine arch. The follow-up lasted 3 years and 4 months and the results were maintained, preserving the occlusal and facial characteristics.
\end{abstract}

KEYWORDS: Orthodontics. Impacted tooth. Tooth abnormalities.

\section{INTRODUCTION}

The eruption of permanent teeth is a combination of genetic and environmental factors in which, from a predetermined path at a given time, the tooth germ developing in the bone cavity continues toward the oral cavity up to reaching its functional occlusion (GRIPPAUDO et al., 2018). The delay in the eruption process of a tooth or the position change of its adjacent teeth may represent clinical signs of retention. These retentions may cause problems such as position changes, root resorptions, and periodontal damages in adjacent teeth (ERICSON; KUROL, 1987. STRBAC et al.,
2012. USCAR et al., 2017). Moreover, in more severe and rare cases, cysts and tumors may be formed, which would result in greater bone loss and even tooth loss (PARKIN et al., 2017).

Any deviation from the eruptive path of a tooth is called ectopic eruption. The consequences of this phenomenon go from the retention of the tooth in question up to the resorption of permanent adjacent teeth (ERICSON; KUROL, 1987). The long eruption path of maxillary canines may be considered a primary reason for their palatal impaction instead of a development variation (PECK; PECK, L; KATAJA, 1994). Except for the third molars, the teeth with higher impaction 
incidence are maxillary canines, with values between $1 \%$ and $3 \%$, which is influenced by the ethnicity of the population studied (MATHEWS; $\mathrm{KOKICH}$, 2013) Canine impaction is usually associated with an atresic maxilla and lack of arch space, thus requiring associated orthopedic, orthodontic, and/or surgical treatments (SCHINDEL; DUFFY, 2007). The early diagnosis favors treatment by intercepting the problem and allowing the practitioner to continue traction, preventing the resorption of adjacent teeth (BISHARA 1992. LANGBERG; PECK, 2000 CRESCINI et al., 2007). The treatment protocols usually include space opening, rapid maxillary expansion (RME), surgical exposure of the impacted tooth, and traction. In some cases, after RME and space opening, the tooth erupts and surgical procedure is not required (BACCETTI et al., 2009).

Several studies have shown that the closed traction technique of impacted canines favors their periodontal condition and preserves the supporting structures of adjacent teeth (QUIRYEN et al., 2000. Kokich, 2004. CRESCINI et al., 2007. INCERTIPARENTI et al., 2016). There are different dental bonding techniques for traction, such as accessory bonding or incisal tooth drilling. The choice for the latter occurs due to the set of favorable characteristics such as the maintenance of a larger portion of the dental follicle, no chemical aggression on the supporting adjacent tissues and the follicle, and no need for a new surgical procedure, considering it eliminates the occurrence of accessory bonding failures (HANSSON; RINDLER, 1998. CAPELOZZA FILHO et al., 2011).

After securing the accessory to the teeth for traction, it is important that traction forces are controlled and movement is individualized. The use of segmented mechanics meets such needs, allowing constant and predictable tooth movements (CAPELOZZA FILHO et al., 2007). The repositioning of ectopic canines minimizes unwanted effects such as the intrusion of adjacent incisors and premolars, considering that the force is applied directly on the traction tooth (LINDAUER; ISAACSON, 1995). It also allows an improved root positioning in the alveolar bone relative to the mechanics of the continuous arch, using the ability for individual torque application on the target tooth (CAPELOZZA FILHO et al., 2007). Given the above, this case report aims to illustrate the guided traction of an impacted maxillary canine using segmented mechanics.

\section{CASE REPORT}

\section{Diagnosis}

Female patient aged 9 years and 4 months, who complained during the orthodontic assessment about the positioning and size of the maxillary incisors. The facial diagnosis showed the absence of passive lip sealing and slight mandibular deviation to the right, resulting in facial asymmetry. The lower facial third was enlarged and the profile was slightly convex with closed nasolabial angle (Figure $1)$.

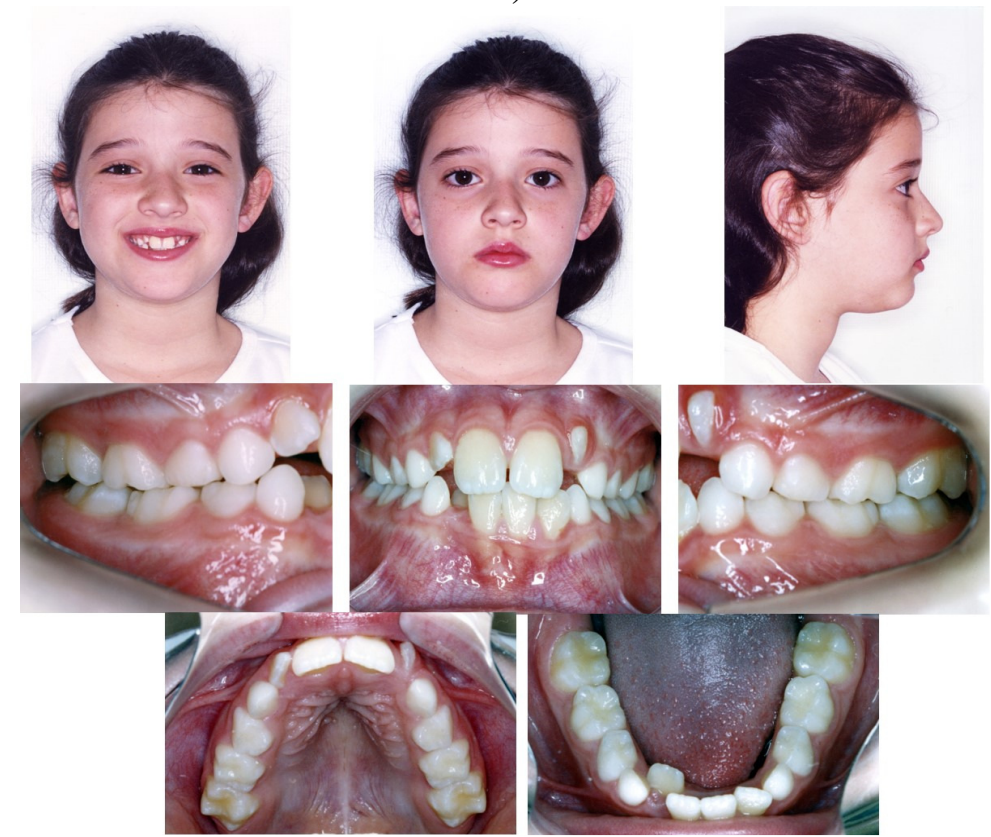

Figure 1: Smile, frontal, profile, and intraoral photographs at the beginning of treatment. 
In the intraoral assessment, the patient presented a Class I molar relationship with rotation (mesial) of tooth 16 and eruption of teeth 12 and 22, the latter with rotation. The lower intercanine distance was small with no room for tooth 42 , which was in the lingual aspect. The dental arches were triangular with reduced upper intermolar distance and deep palate, which are characteristics of an atresic maxilla. Overjet and overbite was normal. The upper dental midline matched the sagittal plane and the lower midline was deviated $3 \mathrm{~mm}$ to the right (Figure 1).

In the radiographic analysis, the patient presented all normal deciduous and permanent teeth at different stages of rhizogenesis (Figure 2).

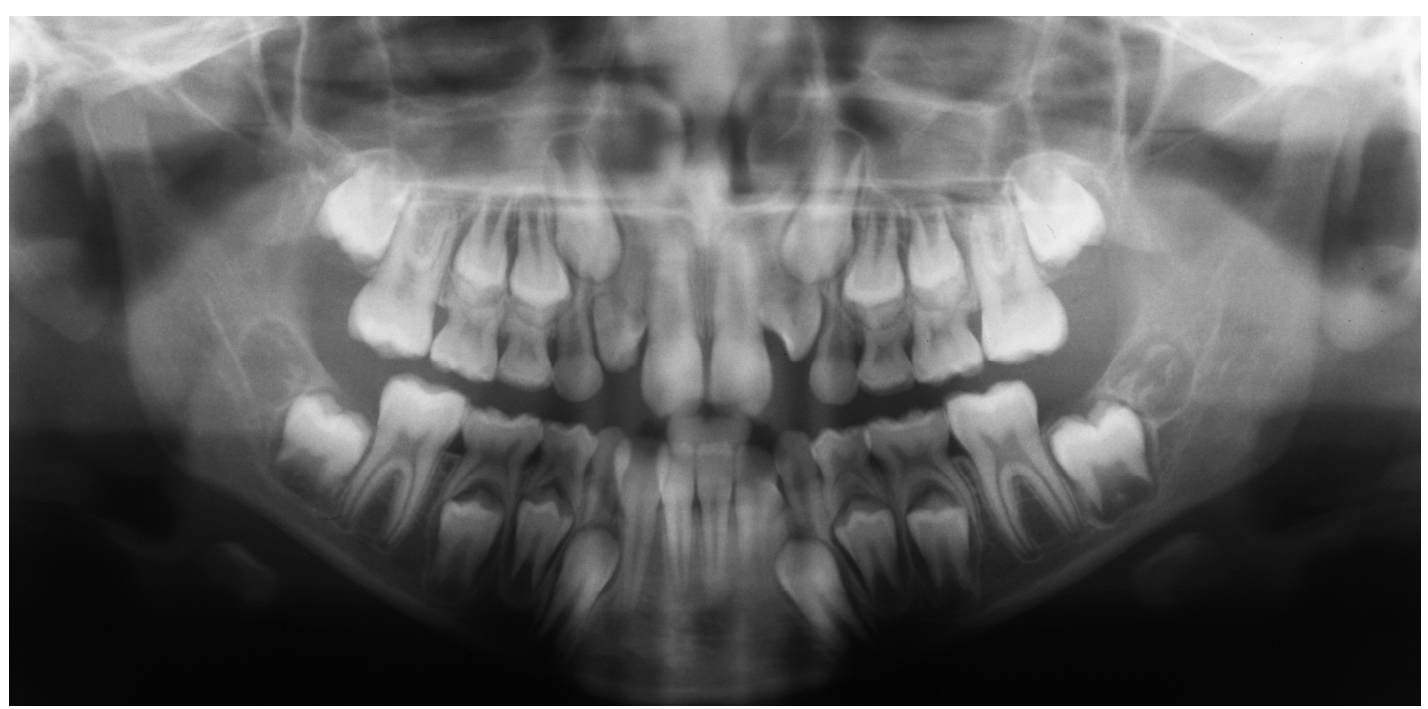

Figure 2: Initial panoramic radiograph. The patient is in the mixed dentition at the first temporary period.

In the intraosseous relationship, the teeth were well positioned, except for teeth 22 and 23, due to the lack of room for eruption (Figure 2). The lateral facial radiograph showed satisfactory inclination of maxillary and mandibular incisors.
The body of the mandible is larger than the ramus. The gonial angle is increased, producing a clockwise rotation in the mandible, which justifies the slightly convex profile (Figure 3 ).

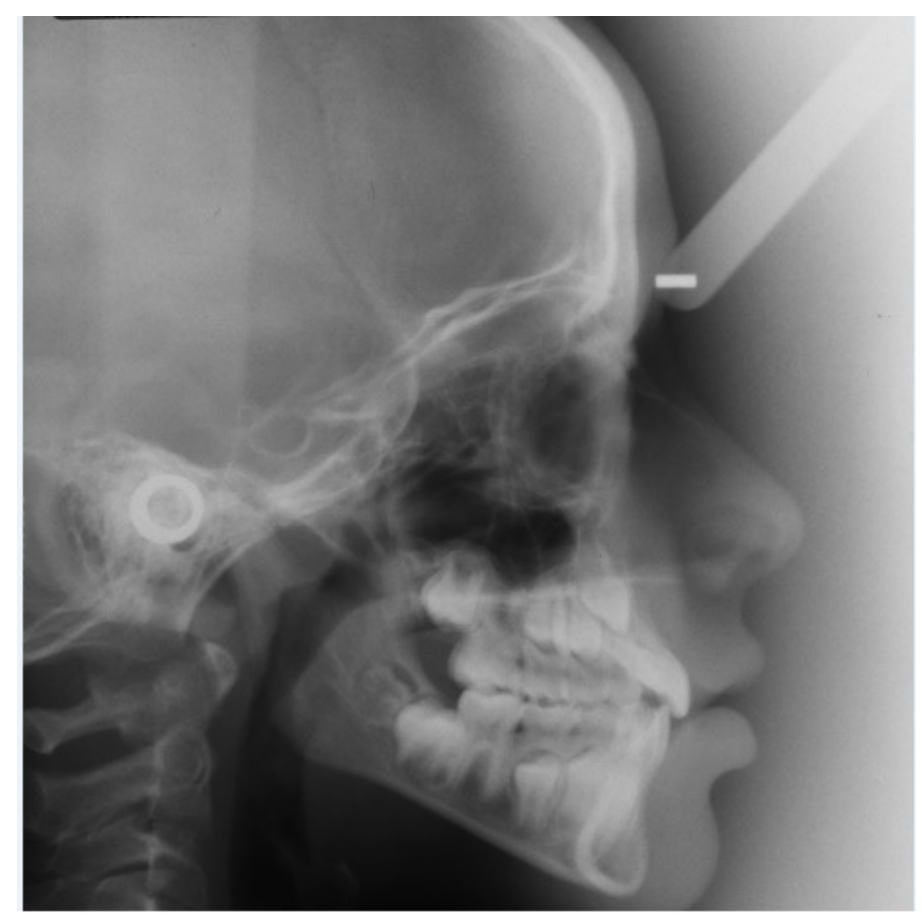

Figure 3: Initial teleradiograph. 


\section{Treatment plan}

From the diagnosis, a two-phase treatment was proposed. The intercepting phase aimed to expand the maxilla (RME) using modified Haas (Figure 4), thus increasing the room for permanent maxillary canine eruption and correcting the maxillary transverse discrepancy. The interceptive management of the maxillary arch would prevent the lateral incisor root from collapsing with the crown of the maxillary left canine (tooth 23), thus repressing a potential root resorption. For the mandibular arch, the use of a lip bumper was proposed to eliminate lip pressure and allow the proclination of lower incisors, recovering the space for tooth 42 .
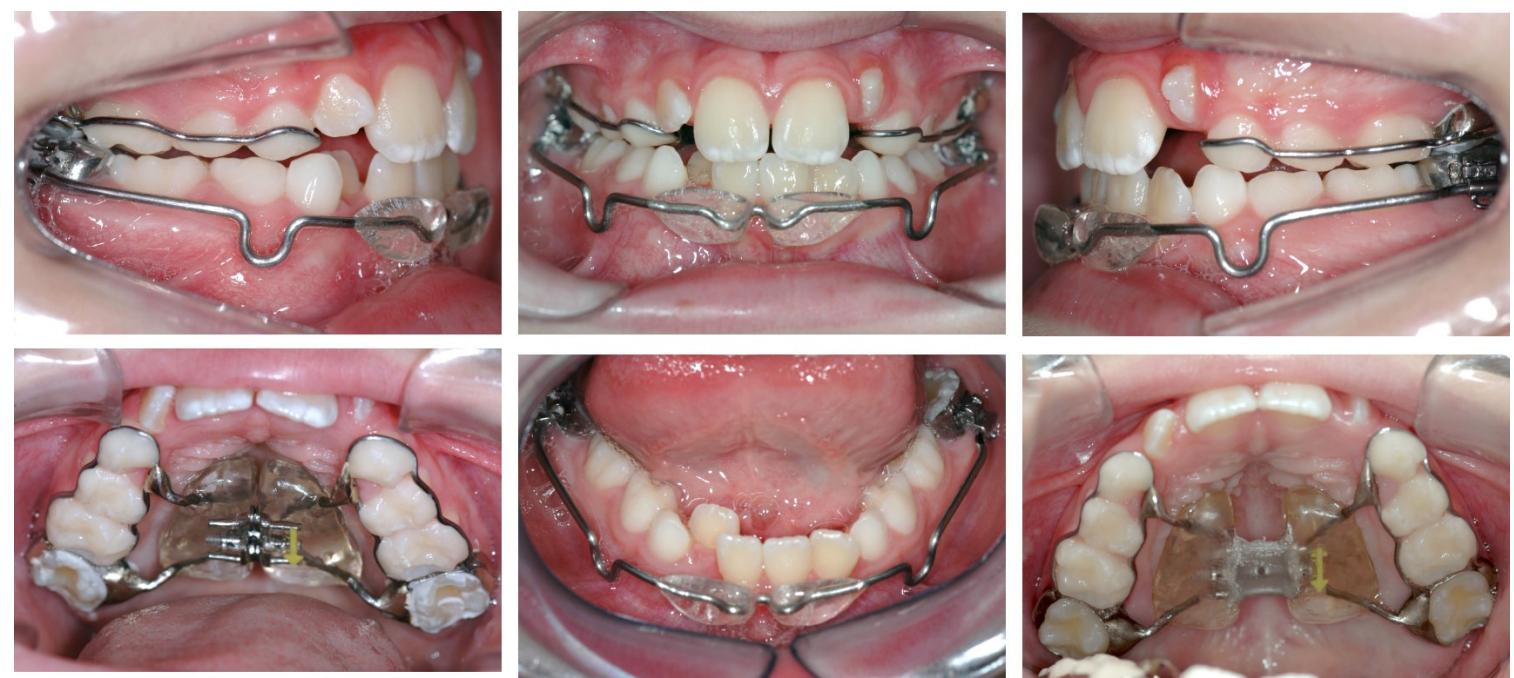

Figure 4: Beginning of RME and lip bumper installation. A wire extension was welded to the expander and prolonged through the buccal and palatal aspects up to the deciduous canines, aiming to expand this area and provide an optimum maxillary morphology.

For the second treatment phase, fixed corrective orthodontics and traction of tooth 23 were proposed. The surgical access of the maxillary canine was performed and the traction device was installed. A passive transpalatal arch was planned to support the segmented mechanics. For the retention period, a Wraparound plate was designed for the maxillary arch as well as a fixed intercanine retainer (3x3) of 0,6 mm wire for the mandibular arch.

\section{Progress of the first treatment phase}

After the responsible persons consented, the first treatment phase was initiated. The modified Haas appliance was installed, supported by bands on the permanent molars and produced with $1.2-\mathrm{mm}$ stainless steel wire. A $0.9-\mathrm{mm}$ steel wire was welded around the deciduous molars and canines through the palatine, passing by the same teeth through the buccal aspect and back to the band of the permanent molars, on both sides (Figure 4). The activation protocol included one full round per day in the expander screw (2/4 round in the morning and $2 / 4$ round at night) in the first five days. From the sixth day to the end of expansion, only a half activation round was performed (1/4 in the morning and $1 / 4$ at night). The patient was assessed weekly during the activation period and at the end of it with transverse correction, the expander screw was locked with acrylic resin. The lip bumper was adapted in a double tube welded on the buccal aspect of the bands of teeth 36 and 46, and it was away from the mandibular incisors. The lip bumper was activated transversely to promote the buccal inclination of teeth 36 and 46 (Figure 4). After six months of treatment, both the lip bumper and the modified Haas appliance were removed.

\section{Previous clinical characteristics of the corrective orthodontic treatment}

The patient was followed-up every six months and after 25 months the second treatment phase was initiated (patient was 12 years and 1 month old). Thus, new documentation was requested for assessment. Figure 5 shows the result of the first phase with the eruption of teeth 12 and 22 , and tooth 42 in a new arch position.

The patient still presents a slightly convex profile, but with signs of mandibular growth, as well as a closed nasolabial angle without passive lip sealing, but with less compression of the mental muscle. The lower third of the face was more expressive and the mandibular growth in this phase showed a slight facial asymmetry (Figure 5). The patient was at the end of the second temporary 
period with teeth 12 and 22 still rotated. The mandibular dental midline was corrected and it matched the sagittal plane, as shown in Figure 5.

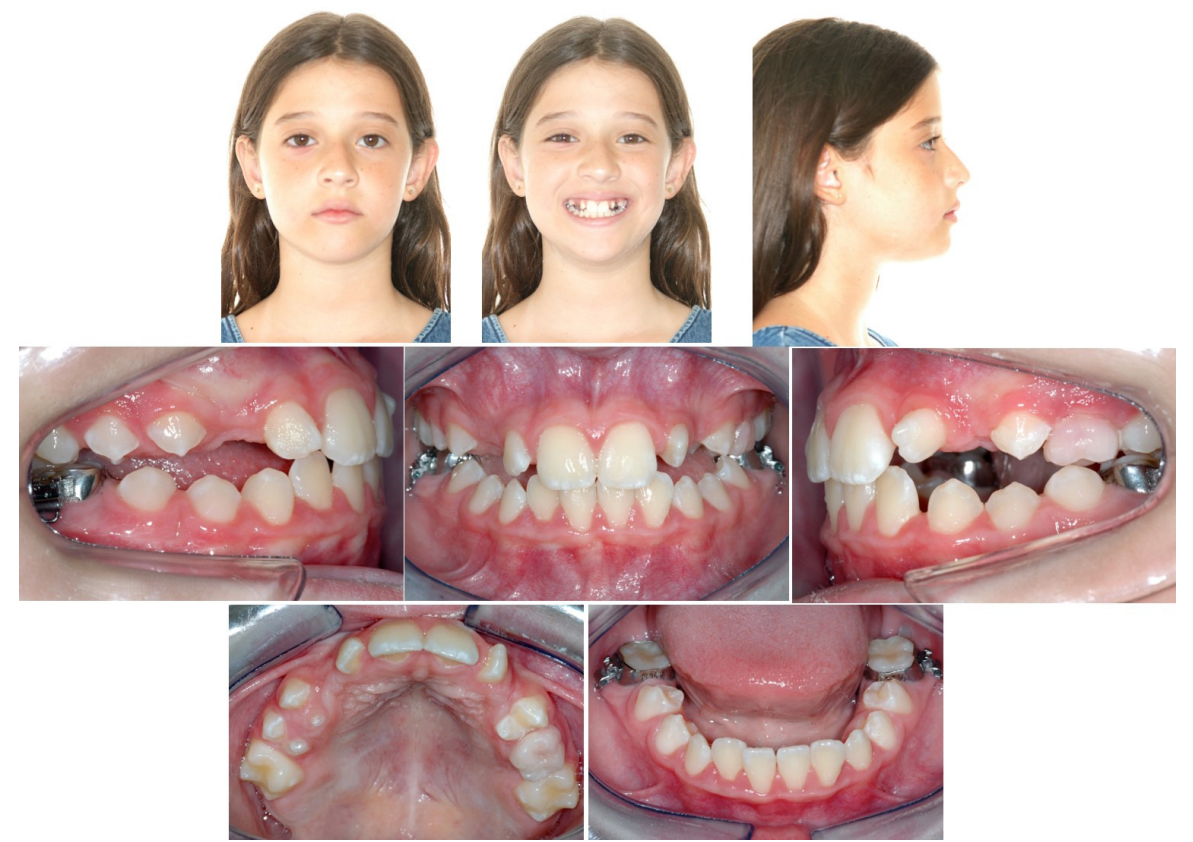

Figure 5: Frontal, smile, profile, and intraoral photographs at the beginning of corrective orthodontic treatment.

The poor positioning of tooth 22 was an indication of potential retention of tooth 23. Periapical radiographs were requested, using the Clark technique for assessing the intraosseous

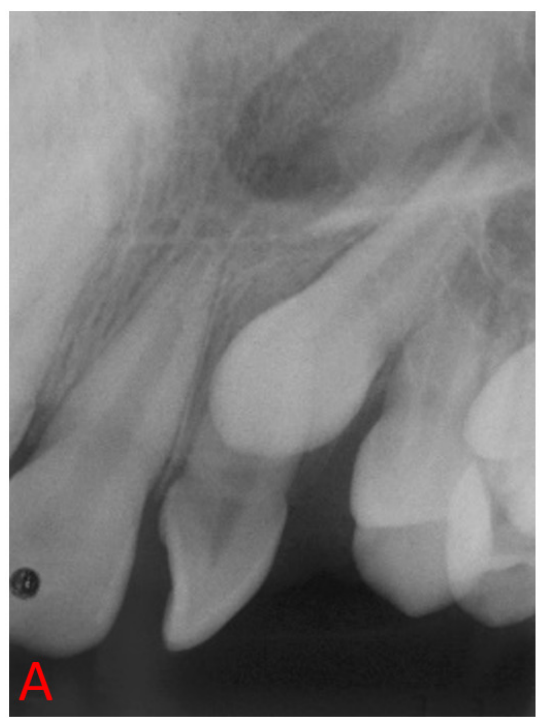

canine position. It was confirmed radiographically that the canine was in a path of collision with the root of tooth 22 (Figure 6).

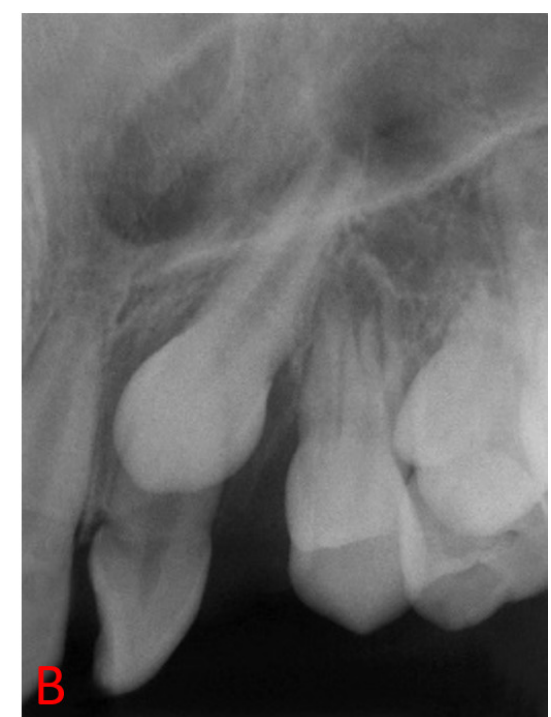

Figure 6: Clark's technique. This technique aims to find the actual position of tooth 23. In image A, the radiographic shot is in the orthoradial position and in image $\mathrm{B}$, it is in the distoradial position.

It was observed that the canine crown was positioned mesially to the lateral root, which was confirmed during the surgical access (Figure 7). In order to reduce the risk of losing the bonded accessories that would traction the maxillary canine, the enamel was drilled for later canine traction. This enamel drilling was later filled in with restorative material (Figure 7). 

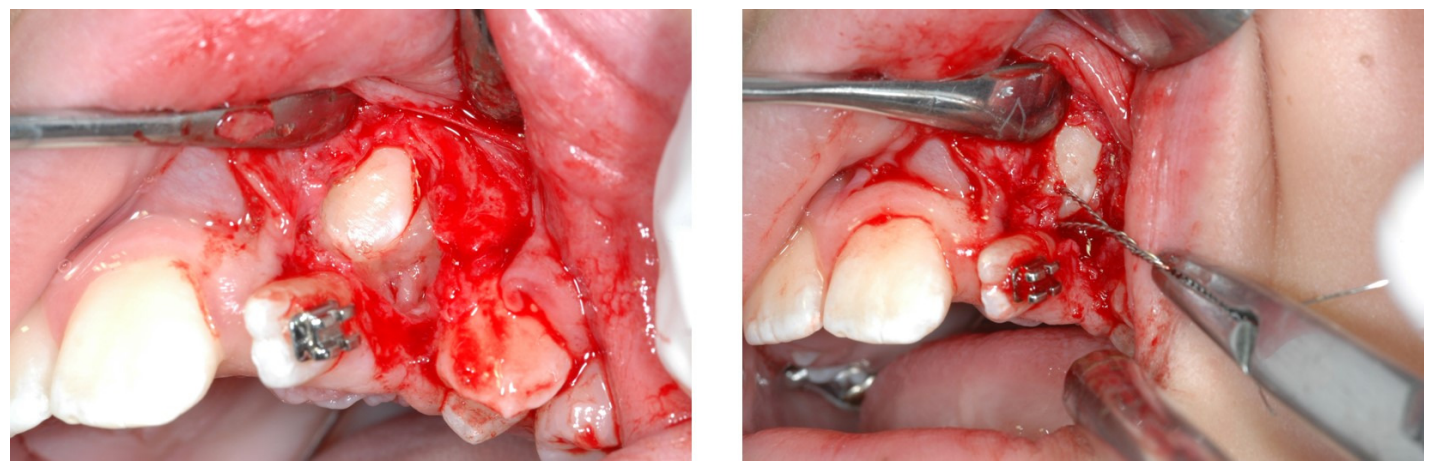

Figure 7: Surgical access for inserting the traction device. Notice the small hole required for wire installation.

\section{Segmented mechanics}

For the segmented mechanics, a passive palatal arch was produced, supported on teeth 16 and 26. Initially, an edgewise bracket was bonded to the maxillary left incisor so that it was later possible to apply torque on the root, aiming to improve the relationship with the maxillary left canine crown.
The PTA supported the cantilever produced with the 0.019" x 0.025" Titanium Molybdenum Alloy (TMA) wire (3M/Abzil ${ }^{\mathrm{TM}}$, São José do Rio Preto, SP, Brazil). The direction established for the traction of tooth 23 would be distal and downward, and later the tooth would be positioned in the arch (Figure 8).
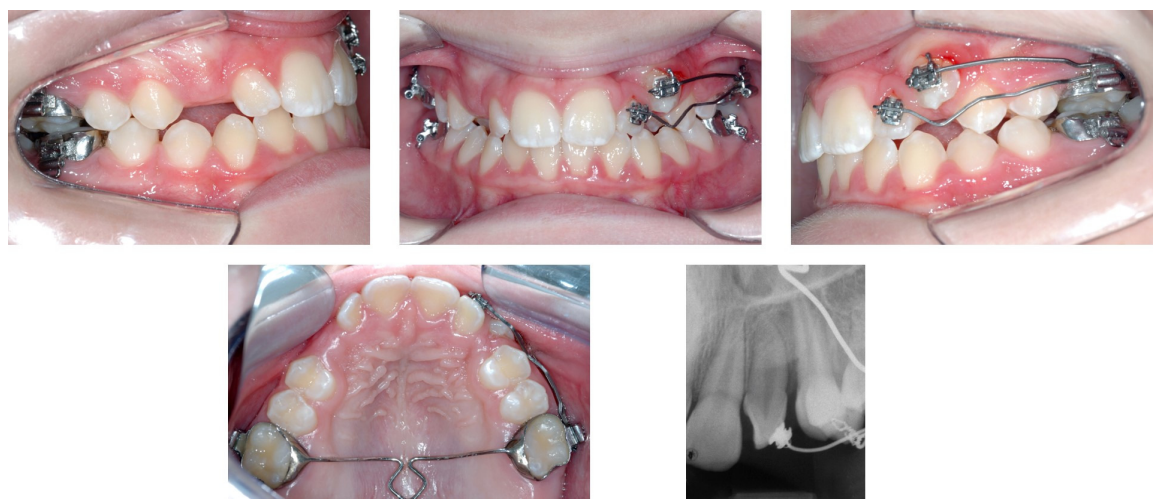

Figure 8: Tooth movement initiation with segmented arch technique (SAT). The PTA stabilized the movements of the cantilevers, thus canceling out all potential negative reaction.

After four months of therapy with segmented mechanics, all appliances were removed and only the PTA was maintained. Figure 9 shows an improvement in positioning and in the relationship between the maxillary left incisor and maxillary left canine. In this phase, the patient started to be assessed every 3 months.
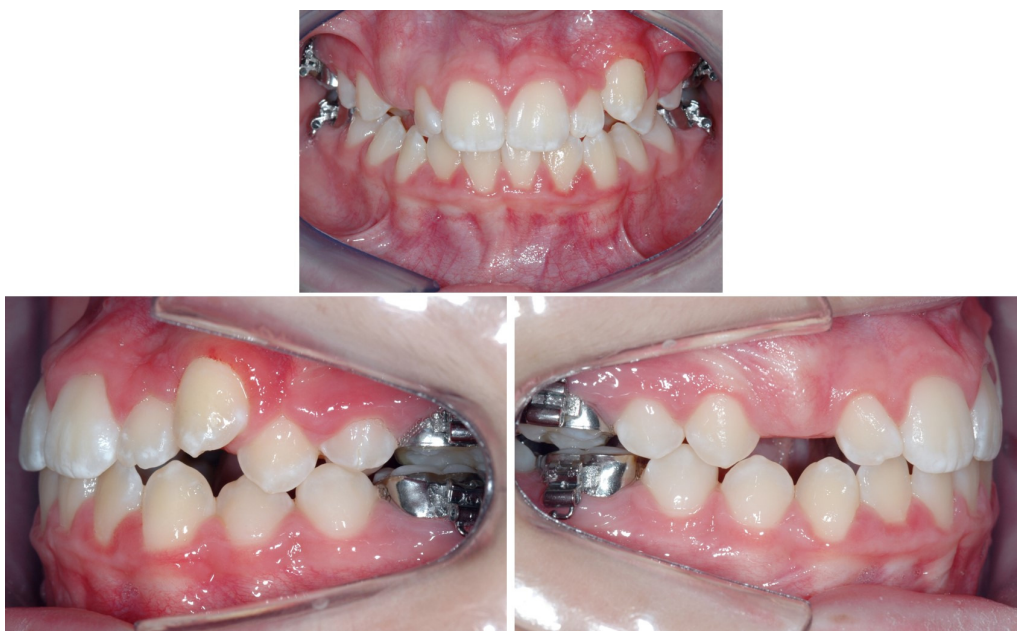

Figure 9: End of the SAT. Tooth 23 is in a more satisfactory position. 


\section{New RME protocol and continuous arch mechanics}

After 2 years and 2 months of follow-up, the patient was 14 years and 4 months old. The facial analysis presented a straight profile and increased lower third of the face. The chin-neck line was enlarged, facial asymmetry remained slight, and there was still no passive lip sealing. The intraoral assessment showed the presence of all teeth, except for the third molars. There was a direct subdivision Class III molar relationship and crowding in the upper and lower anterior region. The higher mandibular growth and development turned the maxillary relationship unsatisfactory, requiring a new maxillary transverse correction (Figure 10).
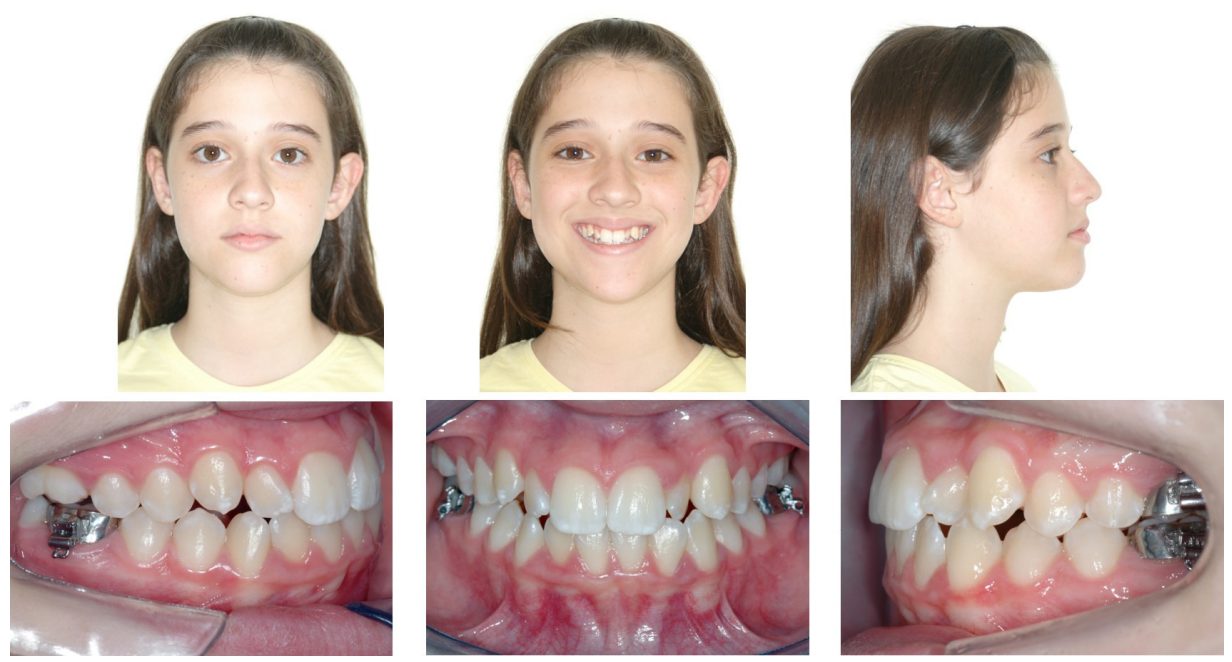

Figure 10: New RME initiation and continuous arch mechanics. The perimeter to be gained with the new expansion aims to facilitate maxillary alignment and leveling.

From this assessment, a new RME was performed according to the same protocol of the first one. Three months later, the Capelozza Pattern III fixed appliance (3M/Abzil ${ }^{\mathrm{TM}}$, São José do Rio Preto, SP, Brazil) was installed in the mandibular arch. Stripping was performed distally in teeth 33 and 43 and mesially in teeth 34 and 44 . The initial wire was 0.014" NiTi (3M/Abzil ${ }^{\mathrm{TM}}$, São José do Rio
Preto, SP, Brazil) and laceback ligatures were installed for space closing and proclination restriction of lower incisors. After 2 months of mechanics, with the 0.018" steel wire in the mandibular arch, a Capelozza Pattern III fixed appliance was installed in the maxillary arch only as a support to keep the maxillary and mandibular dental midlines coinciding (Figure 11).
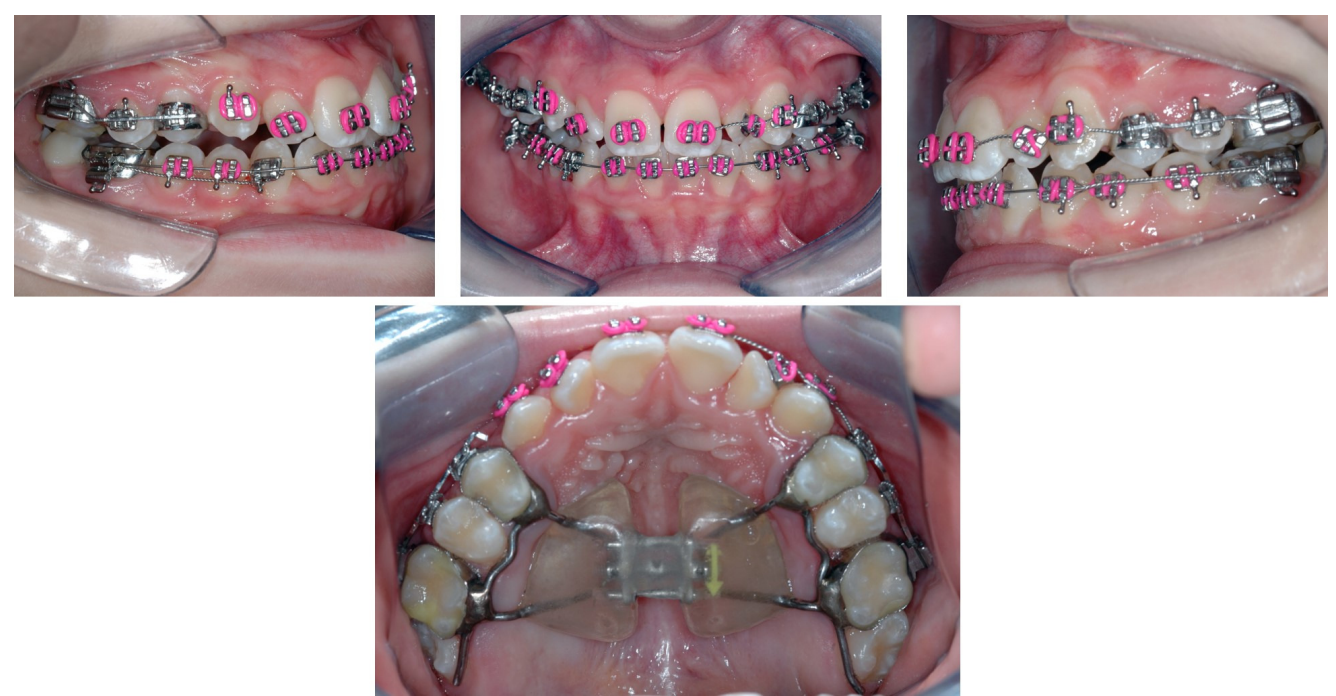

Figure 11: Second RME finished. Notice that alignment and leveling are not completed yet. The wire was extended up to the second molars so they would follow the expansion. 
After the retention period of the RME, the alignment of the maxillary arch was initiated with a 0.014" NiTi wire (3M/Abzil ${ }^{\mathrm{TM}}$, São José do Rio Preto, SP, Brazil), developing up to the 0.019" $\mathrm{x}$
$0.025 "$ steel wire. The alignment of the mandibular arch was finished with a 0.020 " steel wire. First and third order bends were applied when necessary (Figure 12).
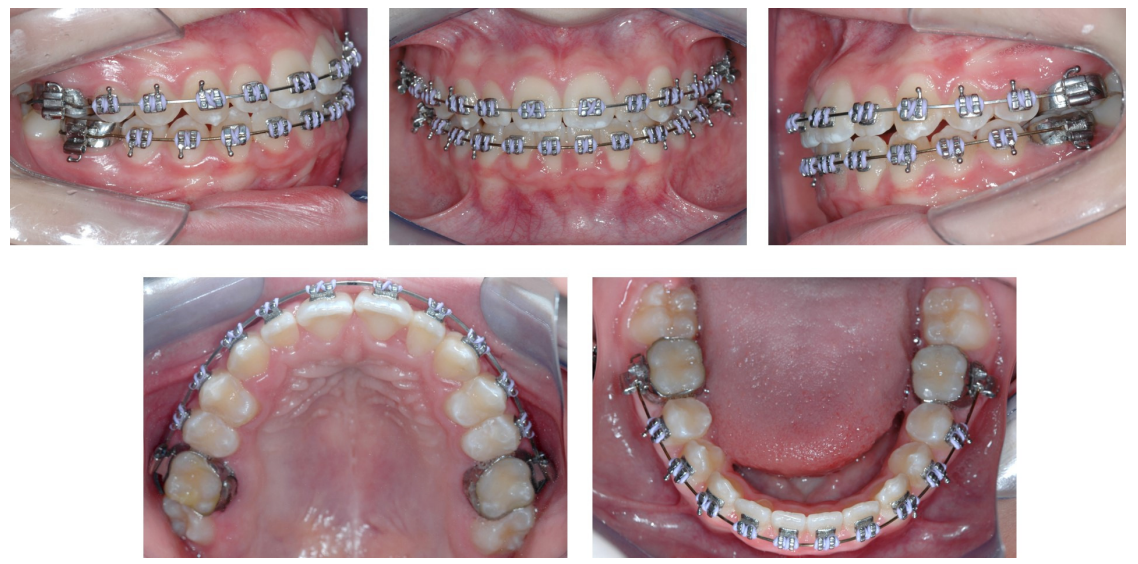

Figure 12: Alignment and leveling phase. Folds were made when necessary to assist finishing.

After 1 year and 4 months of starting the fixed orthodontic therapy phase, all treatment objectives were reached, the orthodontic appliance was removed, and the retention phase was initiated. A removable Wraparound plate was placed in the maxillary arch and a fixed intercanine arch with 0.6$\mathrm{mm}$ steel wire was placed in the mandibular arch (3x3). The patient was instructed to use the upper retainer for an average of 18 hours in the first six months and for 12 hours in the following months. After that, the retainer should be used only at night.

\section{Result and follow-up}

Figure 13 shows the results of the two-phase orthodontic treatment. It may be observed the enlarged mandibular facial third, satisfactory nasolabial angle, and slightly increased chin-neck line. The sagittal relationship is balanced and with a straight profile. At the end of the treatment, lip sealing became passive.

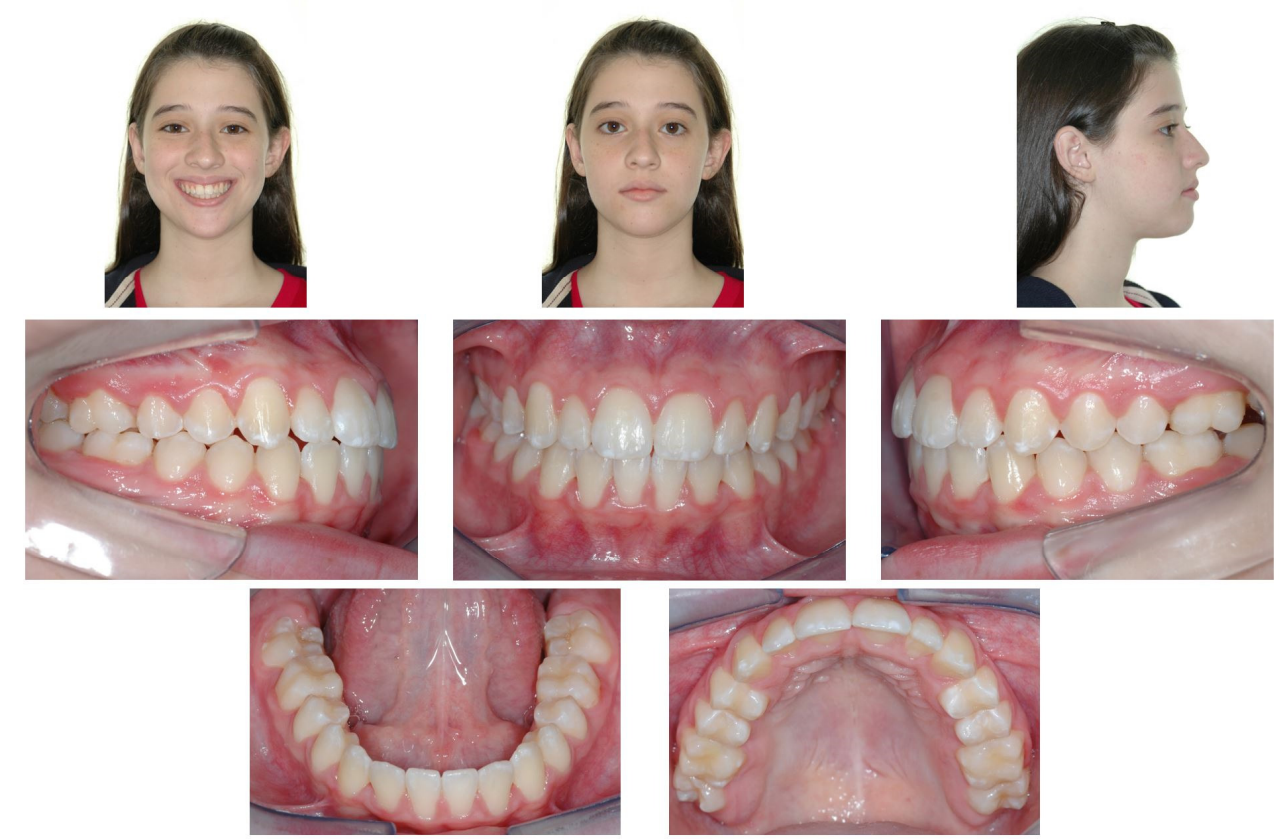

Figure 13: Frontal, smile, profile, and intraoral photographs showing the result of the second treatment phase.

In the final intraoral assessment, a stable occlusion is observed with proper alignment and leveling, as well as normal overbite and overjet. The canine relationship was established as $1 / 4$ Class II on 
the right side due to the compensatory mesial angulation of maxillary canines. The molars are in Angle Class I. The arches present transverse correction with a balanced buccal corridor and a more pleasant smile (Figure 13). The panoramic radiograph shows the effects of the mesial angulation introduced with a compensatory purpose in maxillary canines (Figure 14). The third molars show development and teeth 38 and 48 were suspected to be impacted. There was no major root resorption.

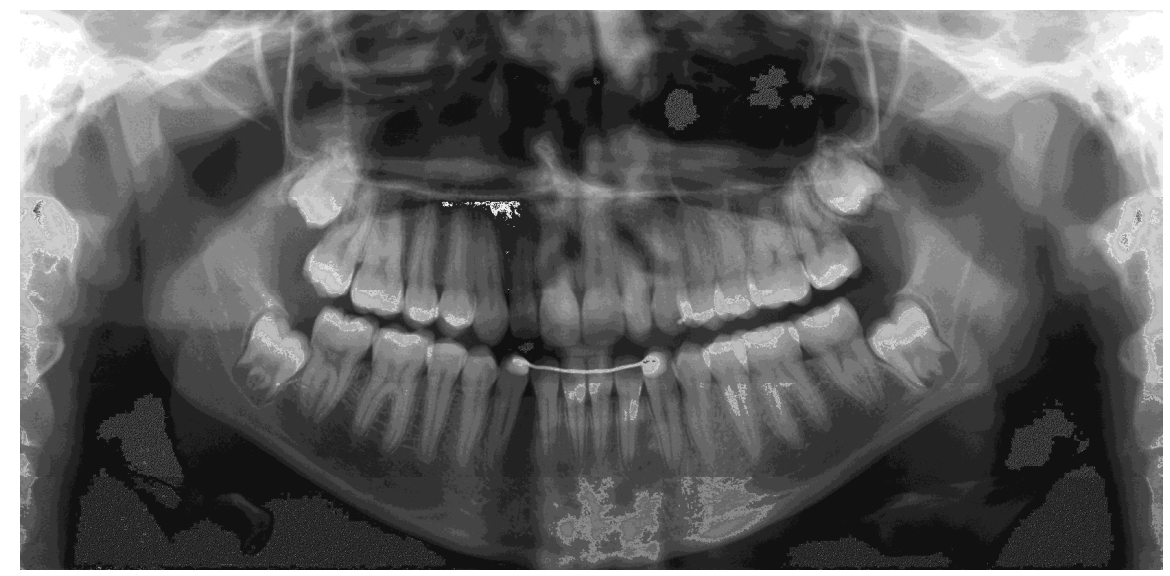

Figure 14: Final panoramic radiograph. Presence of developing third molars.

A new follow-up was performed after 3 years and 4 months, in which the patient was 17 years and 4 months old (Figure 15). The facial characteristics were preserved and occlusion remained stable. Even without correlation between joint disorder and occlusion, the patient did not present signs or symptoms of joint disorder. Dental aesthetics was satisfactory when smiling, even with a slight relapse of maxillary left incisor rotation.
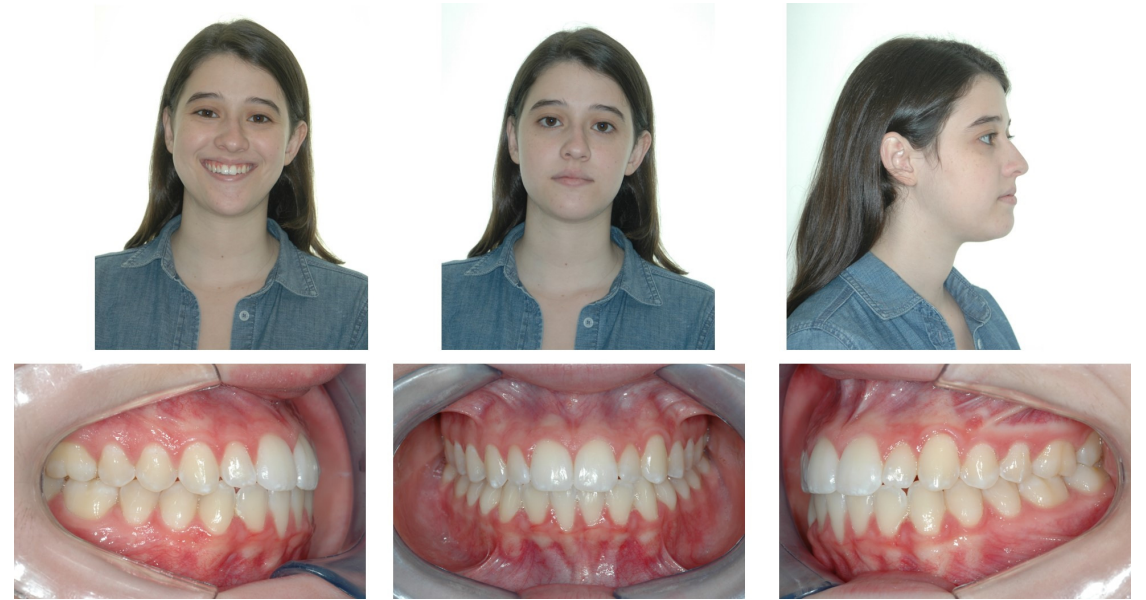

Figure 15: Control 3 years and 4 months after the end of treatment. The results were stable, showing occlusal balance.

\section{DISCUSSION}

The maxillary canines present higher prevalence of impaction after the third molars (KIM; HYUN; JANG, 2012). The concept of impaction differs among practitioners. Its definition is a condition in which a tooth remains incorporated in the oral mucosa or bone longer than the normal physiological time for eruption (ANDREASEN; PETERSEN; LASKIN, 1997. KIM; HYUN; JANG, 2012).
The conventional radiographic methods are used routinely in the daily clinical practice for diagnosing correctly the position of the impacted canine and for creating an efficient treatment plan. ERICSON and KUROL (1987) were guided by periapical radiographs, occlusal film projections, and panoramic images, creating five sections to determine the position of impacted canines. They affirm that when the cuspid of the impacted canine is positioned mesially to the lateral incisor (sections 1 and 2), the risks of root resorption of the adjacent 
teeth increase and optimize the traction difficulties (ERICSON; KUROL, 1987). BRUSVEEN et al. (2012) have also been guided by conventional radiographs, creating five horizontal levels to determine the position of the impacted canine. It is a great challenge to determine the position of the crown and root of the impacted canine and its proximity to neighboring teeth. In the clinical examination, it is almost impossible to determine crown, shape, and pathology abnormalities of an impacted tooth (BACKER; CHAUSHU; CHAUSHU, S. 2010).

The use of three-dimensional images has been valuable to precise the position of an impacted maxillary canine (BRUSVEEN et al., 2012). A cone beam computed tomography study showed higher frequency of root resorption of maxillary incisors in the presence of impacted canines than conventional radiographs, which validates it as a more efficient method (WALKER; ENCISO; MAH, 2005).

Unerupted canine traction has an obscure prognosis (BACKER; CHAUSHU; CHAUSHU, S. 2010. CAPELOZZA FILHO et al., 2011). The possibility of failure is high, considering that it depends on numerous variables (BACKER; CHAUSHU; CHAUSHU, S. 2010). Even with so many uncertainties in the prognosis of traction, a greater neglect would be to leave the crown of tooth 23 in a collision path with the root of tooth 22 , to which the consequences for the root would be of a higher magnitude (LEONARDI et al., 2004). In the presence of impacted maxillary canines, the resorption of central or lateral incisors is potentiated in almost 50\% of cases (AMICO et al., 2003). The root resorptions of maxillary incisors often go unnoticed due to the difficult diagnosis with the traditional radiographic techniques, considering that canine overlap in periapical radiographs may mask the findings (ERICSON; KUROL, 1988). Given these limitations, most studies report low rates of root resorption in maxillary incisors caused by impacted maxillary canines, which produces a lower clinical significance (ERICSON; KUROL, 1988).

When the surgical access is performed exposing the crown of the unerupted canine, the traction may be prepared by looping, accessory bonding, or enamel drilling for canine traction (EDCT) (CAPELOZZA FILHO et al., 2011). Accessory bonding for canine traction (ABCT) may be the most selected technique because it prevents tooth structure wear (CAPELOZZA FILHO et al., 2011). However, the EDCT was used in this study for its advantages of lower risk of a new surgical procedure, lower tissue handling, and lower surgical time and force application on the long axis of the tooth with optimum magnitude (LEONARDI et al., 2004). As restorative materials evolve, the restoration of the leaked natural area does not represent an inconvenient.

The segmented arch technique (SAT) was the most viable proposal for resolving casualties such as the traction of tooth 23 , correcting the position of tooth 22 and improving the position of both roots. Applying the biomechanical principles with the SAT minimizes the side effects, exclude patient cooperation, and promotes the use of light and constant forces with predictable movements (BURSTONE, 1962. CALDAS et al., 2014). The transpalatal arch was attributed as anchorage unit (CALDAS et al., 2014), which is decisive for therapy success (BURSTONE, 1962). Poor anchorage was the reason for $48.6 \%$ of impacted canine traction failure in the study by BACKER et al. (2010). A TMA wire with intermediate characteristics between steel and NiTi that could provide a light and constant force during mechanics was used as a support arm. Different from the conventional techniques that used a continuous wire with the same alloy, the SAT allows the movement of only one tooth with the possibility of working with different alloys (CALDAS et al., 2014). As prescribed by BURSTONE et al. (1995), the SAT allows applying concepts such as horizontal force and torque in a controlled and predictable way. Canine traction started with the TMA wire (support arm) bonded to the traction device in the crown of tooth 23 , anchored by the transpalatal arch. A horizontal force (Figure 8) of $40 \mathrm{~g}$ to $60 \mathrm{~g}$ was applied on the buccal aspect (BURSTONE; STEENBERGEN; HANLEY, 1995). Every time a force is applied ignoring the center of resistance (Cres) that is in the center of the root of the tooth involved, it produces a rotation movement, and in this case, the crown moved to the buccal aspect (BURSTONE; STEENBERGEN; HANLEY, 1995. CALDAS et al., 2014). It seems obvious to assume that distancing the impacted canine from the root of the adjacent teeth prevents and/or interrupts a root resorption process. Therefore, this maneuver should be considered an absolute priority in this situation (BACKER; CHAUSHU, 2005. BRUSVEEN et al., 2012).

Considering that tooth 23 was present in the occlusal perimeter, the support arm was bonded to the bracket slot and to teeth 23 and 22. The root position of both teeth was corrected by torque (two non-collinear and coplanar forces of equal intensity, but in opposing directions) (BURSTONE; STEENBERGEN; HANLEY, 1995) and second bends. 
The RME was required at two treatment times, considering the more expressive mandibular growth in adolescence. It is well established in the literature that maxillary morphology is directly related to maxillary canine impaction - the narrower the arch shape the higher the impaction prevalence (KIM; HYUN; JANG, 2012).

At first, the mandibular arch was treated with the use of a lip bumper, considering that its versatility allows transverse and sagittal corrections (GROSSEN; INGERVALL; 1995. BUSDRANG; HORTON-REULAND;NEVANT, 2001. MENDESJR et al., 2015). Transversely, there was a correction of inclination to the buccal aspect of mandibular molars. Sagittally, it allowed the buccal inclination of incisors and the distal inclination of the first molars, saving room for the eruption of mandibular premolars (GROSSEN; INGERVALL; 1995. BURSDRANG; HORTON-REULAND; NEVANT, 2001). The sum of effects contributed to the achievement of space for tooth 42 .

The efficiency of the guided canine traction may not be measured only by its orthodontic alignment. The technique applied should promote an adequate movement, preserving the periodontium (HALL, 1977. CRESCINI et al., 2007). The healthy and aesthetically satisfactory periodontal tissue is essential to qualify the success of the therapy ${ }^{10}$. The clinical assessment of the gingival area of tooth 23 shows the proper gingival aspect. The values of pocket depth and keratinized tissue width were normal, corroborating the study by QUIRYEN et al. (2000). The detailed radiographic assessment during pre-treatment is important to design a treatment plan and choose the therapy to be applied, but it may not predict the final periodontal condition of the guided traction of the impacted canine.

When dealing with an impacted canine, the orthodontics specialist should pay attention to diagnose it correctly and design an effective treatment plan. In this case, early treatment was essential for reconfiguring the arch and for canine traction. The segmented arch technique (SAT) allowed therapy success, repressing the adverse effects of the continuous arch. The conventional radiographic diagnosis, although it is not the gold standard, was essential for locating the crowns/roots of the teeth involved and for treatment planning. Enamel drilling for canine traction (EDCT) was effective, allowing the application of adequate force for the guided traction. The concern with the gingival aspect around the canine traction was essential to achieve the satisfactory gingival aesthetics.

RESUMO: A preocupação dos pacientes jovens com a estética do sorriso está cada vez maior, ocasionando na visita precoce ao consultório odontológico. É de grande importância que os profissionais, tanto ortodontistas quanto odontopediatras e clínicos gerais, estejam atentos à possíveis alterações de posicionamento e desenvolvimento que comprometam a estética, visto que isso pode evitar tratamentos ortodônticos complexos no futuro. Este relato de caso descreve o tratamento de uma paciente de 9 anos e 4 meses que na avaliação se queixou do tamanho e posição dos incisivos superiores. Clinicamente apresentou maxila atrésica e dentes 12 e 22 em erupção. $\mathrm{O}$ mal posicionamento do dente 22 alertou para possível retenção do dente 23 . Um tratamento em duas fases foi proposto: uma fase interceptadora e uma segunda fase corretiva. Na interceptadora foi realizada expansão rápida da maxila (ERM), aumentando o espaço para erupção do dente 23 e evitando colapso com o dente 22. Após o período de ativação, o expansor de Haas foi travado e sua remoção feita seis meses após o travamento. Passados 25 meses da remoção, iniciou-se a segunda fase, com ortodontia fixa corretiva e tracionamento do dente 23. Para o tracionamento, foi feita perfuração no esmalte e tracionamento por meio da técnica segmentada, utilizando cantilever de Titanium Molybdenum Alloy (TMA) 0,019" x 0,025" e ancoragem em barra transpalatina passiva (BTP). A utilização desta técnica minimiza efeitos colaterais aos dentes adjacentes ao 23 e a perfuração de esmalte evita possíveis perdas do dispositivo de tracionamento por descolagem. Após 4 meses de mecânica segmentada, removeu-se os dispositivos mantendo a BTP. Passados mais 26 meses, a paciente se encontrava com 14 anos 4 meses, relação molar de Classe III subdivisão direita, apinhamento superior e inferior e relação insatisfatória das bases ósseas, devido ao crescimento excessivo da mandíbula. Foi realizada nova ERM, após 3 meses instalou-se aparelho fixo Padrão III de Capelozza no arco inferior e, após o período de contenção da ERM, instalou-se o aparelho fixo superior. Após 1 ano e 4 meses, removeu-se os dispositivos e se instalou uma placa de Hawley superior, com barra fixa intercaninos de $0.6 \mathrm{~mm}$ no arco inferior. Com acompanhamento de 3 anos e 4 meses, os resultados foram mantidos, preservando as características oclusais e faciais.

PALAVRAS-CHAVE: Ortodontia. Dentes impactados. Anomalia dental 


\section{REFERENCES}

AMICO, R. M.; BJERKLIN, K.; FALAHAT, B. Long-term Results of Orthodontic Treatment of Impacted Maxillary Canines. Angle Orthod, v. 73, n. 3, p. 231-238, June. 2003.

ANDREASEN, J. O.; PETESEN, J. K.; LASKIN, D. M. Textbook and color atlas of tooth impactions. $\mathbf{1}^{\text {st }}$ ed. Copenhagen, Denmark: Munksgaard; 1997. p. 126-66.

BACCETTI, T.; MUCEDERO, M.; LEONARDI, M.; COZZA, P. Interceptive treatment of palatal impaction of maxillary canines with rapid maxillary expansion: A randomized clinical trial. Am J Orthod Dentofac Orthop, v. 136, n. 5, p. 657-661, November 2009. https://doi.org/10.1016/j.ajodo.2008.03.019

BACKER, A.; CHUASHU, G.; CHAUSHU, S. Analysis of failure in the treatment of impacted maxillary canines. Am J Orthod Dentofacial Orthop, v. 137, n. 1, p. 743-754, July 2008.

BACKER, A.; CHUASHU, S. Long-term follow-up of severely resorbed maxillary incisors after resolution of an etiologically associated impacted canine. Am J Orthod Dentofacial Orthop, v. 127, n. 1, p. 650-654, Mach 2005.

BISHARA, S.; E. Impacted maxillary canines: a review. Am J Orthod Dentofacial Orthop, v. 101, n. 2, p. 159-171, March 1992. https://doi.org/10.1016/0889-5406(92)70008-X

BRUSVEEN, E. M. G.; BRUDVIK, P.; MAVRAGANI, M. Apical root resorption of incisors after orthodontic treatment of impacted maxillary canines: A radiographic study. Am J Orthod Dentofacial Orthop, v. 141, n. 1, p. 427-435, July 2012. https://doi.org/10.1016/j.ajodo.2011.10.022

BURSTONE, C. J.; STEEBERGEN, E.; HANLEY, K. J. Modern Edgewise Mechanics \& The Segmented Arch Technique. Glendora: Ormco; 1995.

BURSTONE, C. J. Rationale of the segmented arch. Am J Orthod, v. 48, n. 11, p. 805-822, November 1962. https://doi.org/10.1016/0002-9416(62)90001-5

BUSDRANG, P. H.; HORTON-REULAND, S. J.; NEVANT, C. Nonextraction approach to tooth size archlength discrepancies with the Alexander discipline. semin. Orthod, v. 7, n. 2, p. 117-131, June 2001.

CALDAS, S. G. F. R.; RIBEIRO, A. A.; SIMPLÍCIO, H.; MACHADO, A. W. Segmented arch or continuous arch technique. A rational approach. Dental Press J Orthod., v. 19, n. 2, p. 126-141, Mar-Apr 2014. https://doi.org/10.1590/2176-9451.19.2.126-141.sar

CAPELOZZA FILHO, L.; CARDOSO, M. A.; BERTOZ, F.A. Maxillary canine - first premolar transposition. Angle Orthod, v. 77, n. 1, p. 167-175, Feb. 2007. https://doi.org/10.2319/012906-32R.1

CAPELOZZA FILHO, L.; CARDOSO, M. A.; SIQUEIRA, D. F. Enamel drilling for canine traction: Advantages, disadvantages, description of surgical technique and biomechanics. Dental Press J Orthod, v. 12, n. 5, p. 172-205, Mar- Apr 2011. https://doi.org/10.1590/S2176-94512011000500024

CRESCINI, A.; NIERI, M.; BUTI, J.; BACCETTI, T.; PRATO, G. P. P. Orthodontic and periodontal outcomes of treated impacted maxillary canines: An appraisal of prognostic factors. Angle Orthod, v. 77, n.4, p. 571577, September 2007. https://doi.org/10.2319/080406-318.1

ERICSON, S.; KUROL, J. Incisor resorption caused by maxillary cuspids. A radiographic study. Angle Orthod1, v. 57, n. 4, p. 332-346, September 1987. https://doi.org/10.1016/0889-5406(88)90008-X 
ERICSON, S.; KUROL, J Resorption of maxillary lateral incisors caused by ectopic eruption of the canines. AM J ORTHOD DENTOFAC ORTHOP, v. 94, n. 1, p. 503-513, Jun 1988.

GRIPPAUDO, C.; CAFIERO, C.; D’APOLITO, I.; RICCI, B.; FRAZIER-BOWERS.

Primary failure of eruption: Clinical and genetic findings in the mixed dentition. Angle Orthod, v. 88, n. 3, p. 275-282, May 2018. https://doi.org/10.2319/062717-430.1

GROSSEN, J.; INGERVALL, B. The effect of a lip bumper on lower dental arch dimensions and tooth positions. eur. J. Orthod, v. 17, no. 2, p. 129-134, Apr. 1995.

HALL, W. H. Recent status of soft tissue grafting. J Periodontol, v. 48, n. 1, p. 587-597, May 1977. https://doi.org/10.1902/jop.1977.48.9.587

HANSSON, C.; RINDLER, A. Periodontal conditions following surgical and orthodontic treatment of palatally impacted maxillary canines - A follow-up study. Angle Orthod, v. 68, n. 2, p. 167-172, April 1998.

INCERTI-PARENTI, S.; CHECCHI, V.; IPPOLITO, D. R.; GRACCO, A.; ALESSANDRI-BONETTI, G. Periodontal status after surgical-orthodontic treatment of labially impacted canines with different surgical techniques: A systematic review. Am J Orthod Dentofac Orthop, v. 149, n. 4, p. 463-472, May 2016. https://doi.org/10.1016/j.ajodo.2015.10.019

MENDES-JR, T. E.; LIMA, A. P. B.; MENDES, T. E.; MENDES, C. T.; ROSÁRIO, H. D.; PARANHOS, L. R. Distalization Controlled with the Use of Lip-bumper and Mini-screw as Anchorage: A New Approach. IJO, v.26, n. 1, p. 29-32, April 2015.

KIM, Y.; HYUN, H. K.; JANG, K, I. Interrelati. Interrelationship between the position of impacted maxillary canines and the morphology of the maxilla. Am J Orthod Dentofacial Orthop, v. 141, n.1, p. 556-562, April 2012. https://doi.org/10.1016/j.ajodo.2011.11.015

KOKICH, V. G. Surgical and orthodontic management of impacted maxillary canines. Am J Orthod Dentofac Orthop, v. 126, n. 3, p. 278-283, June 2004. https://doi.org/10.1016/j.ajodo.2004.06.009

LANDBERG, B. J.; PECK, S. Adequacy of maxillary dental arch width in patients with palatally displaced canines. Am J Orthod Dentofacial Orthop, v. 118, n. 2, p. 220-223, May 2000.

https://doi.org/10.1067/mod.2000.104819

LEONARDI, M.; ARMI, P.; FRANCHI, L.; BACCETTI, T. Two Interceptive Approaches to Palatally Displaced Canines: A Prospective Longitudinal Study. Angle Orthod, v. 74, n. 5, p. 581-586, November 2004.

LINDAUER, S. J.; ISAACSON, R. J. One-couple orthodontic appliance systems. Semin Orthod, v. 1, n. 1, p. 12-24, May 1995. https://doi.org/10.1016/S1073-8746(95)80084-0

MATHEWS, D. P.; KOKICK, V. G. Palatally impacted canines: The case for preorthodontic uncovering and autonomous eruption. Am J Orthod Dentofac Orthop, v. 143, n. 4, p. 450-458, April 2013.

https://doi.org/10.1016/j.ajodo.2013.02.011

PARKIN, N.; BENSON, P. E.; THIND, B.; SHAH, A.; KHALIL, I.; GHAFOOR, S.

Open versus closed surgical exposure of canine teeth that are displaced in the roof of the mouth. Cochrane

Database Syst Rev, v. 8, n.8, August 2017.

PECK, S.; PECK, L.; KATAJA, M. The palatally displaced canine as a dental anomaly of genetic origin. Angle Orthod, v. 64, n. 4, p. 249-256, April 1994.

QUIRYNEN, M.; HEIJ, D. G.; ADRIANSENS, A.; OPDEBEECK, H.M.; VAN STEENBERGHE, D.

Periodontal health of orthodontically extruded impacted teeth. A split-mouth, long-term clinical evaluation. J

Periodontol, v. 71, n. 1, p. 1708-1714, May 2000. https://doi.org/10.1902/jop.2000.71.11.1708 
SCHINDEL R, H.; DUFFY, S. L. Maxillary transverse discrepancies and potentially impacted maxillary canines in mixed-dentition patients. Angle Orthod, v. 77, n. 3, p. 430-435, May 2007.

https://doi.org/10.2319/0003-3219(2007)077[0430:MTDAPI]2.0.CO;2

STRBAC, G. D.; FOLTIN, A.; GAHLEITNER, A.; BANTLEON, H. P.; WATZEK, G.; BERNHART, T. The prevalence of root resorption of maxillary incisors caused by impacted maxillary canines. Clin Oral Investig, v. 17, n. 2, p. 553-564, August 2013. https://doi.org/10.1007/s00784-012-0738-9

UCAR, F. I.; CELEBI, A. A.; TAN, E.; TOPCUOGLU, T.; SEKERCI, A. E. Effects of impacted maxillary canines on root resorption of lateral incisors. J Orofac Orthop, v. 78, n. 3, p. 233-240, Feb 2017. https://doi.org/10.1007/s00056-016-0077-6

WALKER, L.; ERICSON, R.; MAH, J. Three-dimensional localization of maxillary canines with cone-beam computed tomography. Am J Orthod Dentofacial Orthop, v. 128, n. 4, p. 418-423, October.

https://doi.org/10.1016/j.ajodo.2004.04.033 